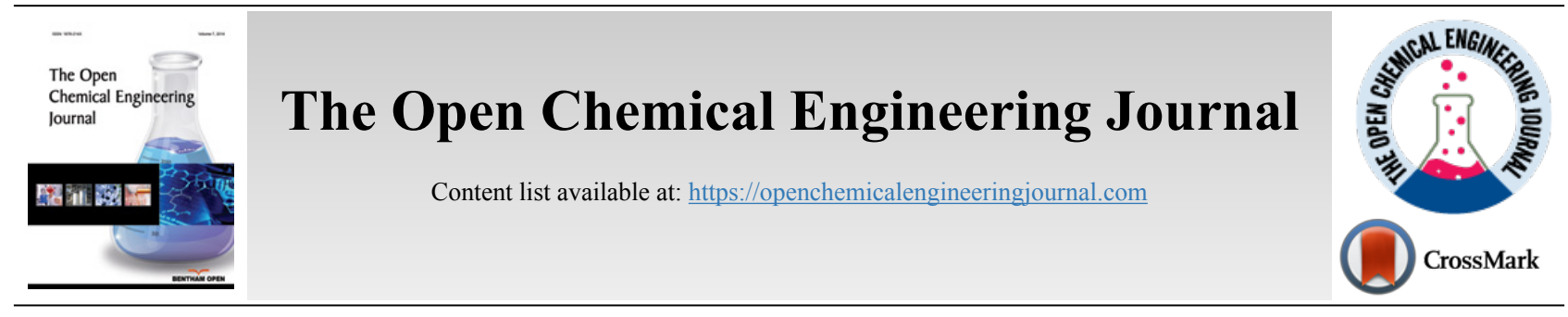

RESEARCH ARTICLE

\title{
Compact Flow-Through Electrochemical Cell - A Novel Perspective in Industrial Manufacture of Perchlorates
}

\author{
Sananth H. Menon ${ }^{1, *}$, G. Madhu ${ }^{2}$ and J. Mathew ${ }^{1}$ \\ ${ }^{I}$ APEP, VSSC, ISRO, Aluva, India \\ ${ }^{2} S O E$, CUSAT, Kochi, India
}

\begin{abstract}
:
Background:

Sodium Perchlorate is one of the major starting intermediate product for the manufacture of various Perchlorates viz, Ammonium perchlorate as solid oxidizer and Strontium Perchlorate as Secondary Injection Thrust Vector Control (SITVC) in launch vehicles. This critical product is manufactured industrially by electrochemical oxidation of Sodium Chlorate solution at the anodic surface. Lead dioxide is preferred in various perchlorate cells because of its low cost. Infrequent detachment of Lead dioxide deposits from the substrate during electrolysis is a grave issue confronted by associated electrochemists in bulk manufacture of chemicals. Moreover, a cheaper alternative for continuous manufacture of Sodium Perchlorate using Lead dioxide electrodes has been an onus among various industrial electrochemists.
\end{abstract}

\section{Objective/ Benefits:}

Development of a suitable compact flow through electrochemical cell using superfluous or detached Lead dioxide crystals as 'particle' electrodes is the major objective of this paper. This compact bed electrochemical cell, is extraordinarily helpful when confronting with lesser reactant concentration or time consuming reactions. Besides, this proposal adds on flexibility in trimming the size of cells when compared with bulky design of conventional cells. Another objective was to demonstrate continuous electrosynthesis of Sodium perchlorate using Lead dioxide without resorting to expensive Platinum.

Method:

A suitable single bed and a dual bed compact electrochemical cell was made using HDPE body, perforated Poly Propylene distributor, detached Lead dioxide particles, nylon mesh, etc. Four such dual bed cells were made for final demonstration for continuous electro synthesis application.

Results:

From various experimental trials, an optimum values for temperature, flow rate and current load were determined as $600^{\circ} \mathrm{C}, 800 \mathrm{~mL} / \mathrm{min}$ and $80 \mathrm{~A}$ respectively, in single bed system. Inorder to avoid current penetration issue, dual bed cells were employed. Subsequently, critical operational strategy and systematic configuration for arrangement of dual bed cells were made for demonstrating continuous bed electrochemical cells.

\section{Conclusion}

An average current efficiency of about $78.5 \%$ could be achieved which is $20-25 \%$ higher than conventional parallel plate electrode system.

Keywords: Compact electrochemical cell, Flow through electrolyser, Lead dioxide, Perchlorate reaction, Isothermal system, Flow rate.

\begin{tabular}{l|l|l|l}
\hline Article History & Received: January 17, 2019 & Revised: February 14, 2019 & Accepted: February 25, 2019
\end{tabular}

\section{INTRODUCTION}

Lead dioxide is used as insoluble anodes in the Perchlorate cells due to its remarkable stability in Perchlorate solutions, higher electronic conductivity and naturally low cost [1]. Rapid formation of non-conducting film on the surface of bare Titanium metal restricts its use as ready-made substrates for the obvious consequence of improper gripping between the support

* Address correspondence to this author at the APEP, VSSC, ISRO, Aluva, India; E-mail: sananth_menon@vssc.gov.in and lead dioxide deposit. This signifies the necessity of a delicate inner coating of costly mixed metal oxides over the Titanium mesh. Though these lead dioxide coated electrodes are sufficiently immobile in batch cells and sufficient care has been taken in providing a very delicate under coating, occasionally lead dioxide deposits gradually lose their attachment with the substrate prematurely. Consequently, the performance of these electrodes degrades necessitating the exclusion of such anodes in order to ger a layer of coating. Though, detached from its substrate, lead dioxide flakes retain 
all their chemical features and their potential as an 'oxidizing agent'.

It is acknowledged from literature that 'particle' electrodes, offer ample electrode specific surface area in comparison with conventional plate type electrode design [1 - 4]. Recently, research interest in this area got increased especially in the electrochemical oxidation of waste chemicals in a highly energy efficient manner. Wang et al. [5] developed an optimal strategy for cell design and operation of an industrial particulate bed electrochemical reactor in treating waste water. Peng et al [6] developed a rotating packed bed reactor for accelerated desulphurization of waste Lead battery paste. In another paper, Wang et al [7] described kinetics for electrochemical oxidation of organic pollutants in detail. A three stage reaction theory involving Charge Transfer Controlled (CTC), Mixed Phase Controlled (MPC) and Mass Transport Controlled (MTC) was reported to describe the kinetics of oxidation of organic pollutants. Though many papers reported the application of particulate electrodes in affluent/waste treatment, not many studies had gone into production of inorganic chemicals, especially in the industrial scale. One of the apprehensive issues in the production of a strategic chemical like Perchlorates are the final disposal of lead dioxide particles peeled out from the substrate metals used in electrochemical cells. This paper highlights the efficient application of superfluous or detached Lead dioxide crystals as 'particle' electrodes in a specially designed compact flow through electrochemical cell. The above cell was utilized for understanding its efficacy in the conversion of Sodium Chlorate to Sodium Perchlorate, which are the preliminary intermediates for the production of solid oxidizers for Space craft launch vehicles. These electrolysers were stacked in a series for demonstrating continuous electro-synthesis of Sodium Perchlorate.

\section{EXPERIMENTAL DETAILS}

Experiments were carried out in 2 different types of compact flow through electrochemical cells, viz. single bed type and dual bed type.

\subsection{Single Bed Type}

The cell was fabricated using Polythene body with envelope dimensions being $20 \mathrm{~cm}$ (ID) x $32 \mathrm{~cm}$ (H). About 6 $\mathrm{Kg}$ of $\mathrm{PbO}_{2}$ particles having an average particle size of 700 microns, were intensely packed in the cell. Poly propylene support plates having perforations, also acting as liquid distributors, with nylon mesh were used at both ends for guaranteeing stiff and leak proof packing. Electrolyte solution fed to the cell through the bottom inlet, leaves the cell by overflowing from the top. This solution is continuously pumped to the electrolyte storage cum feed tank and subsequently comes back to the cell by gravity as shown in schematic sketch (Fig. 1). The electrolyte storage tank was charged with 15 litres of Sodium Chlorate solution having an initial concentration of $700 \mathrm{gm} /$ litre (gpl). Mixed metal oxide coated Titanium tube was used as anodic current feeder while the cathode was SS $316 \mathrm{~L}$. A constant temperature inside the cell was maintained providing the overflow collection tank with a cooling water circulation system encompassing cooling tubes and an electric heater coupled using an interlock system, as shown in Fig. (2).

\subsection{Dual Bed Type}

A dual bed type cell was made in a single bed type for resolving the possible current penetration issues developed inside. Its construction is similar to the single bed type but by repeating one more bed of particles as shown in schematic sketch (Fig. 3).

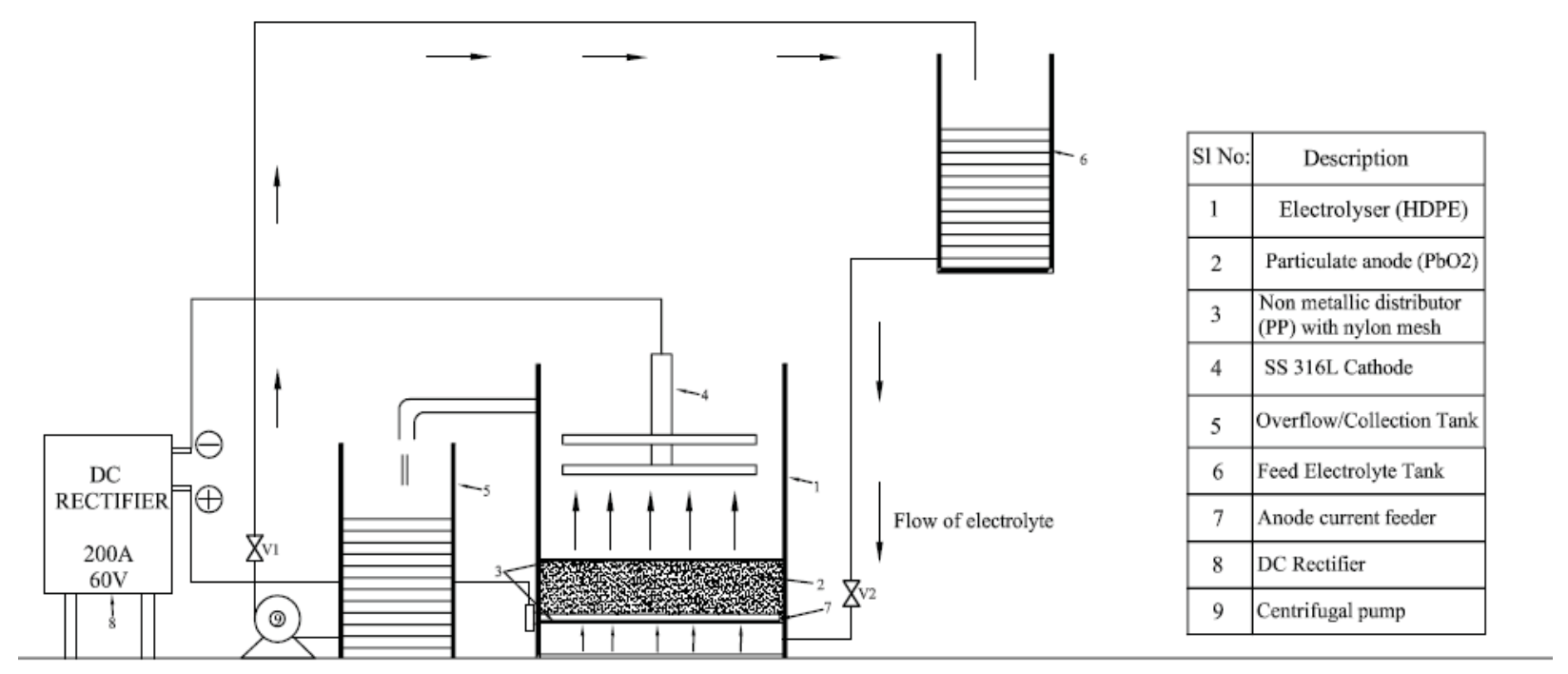

Fig. (1). Experimental Setup. 


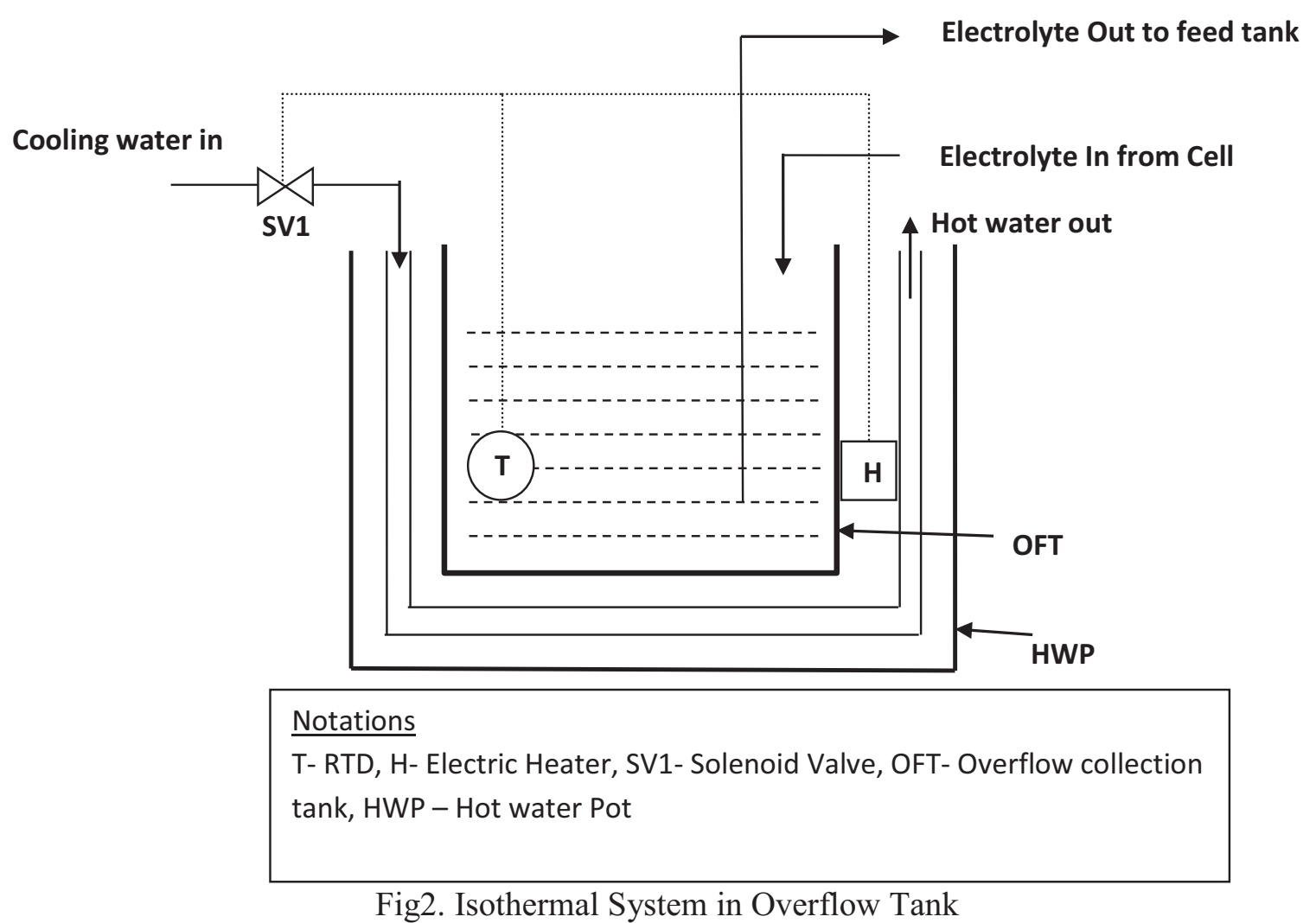

Fig. (2). Isothermal system in overflow tank.

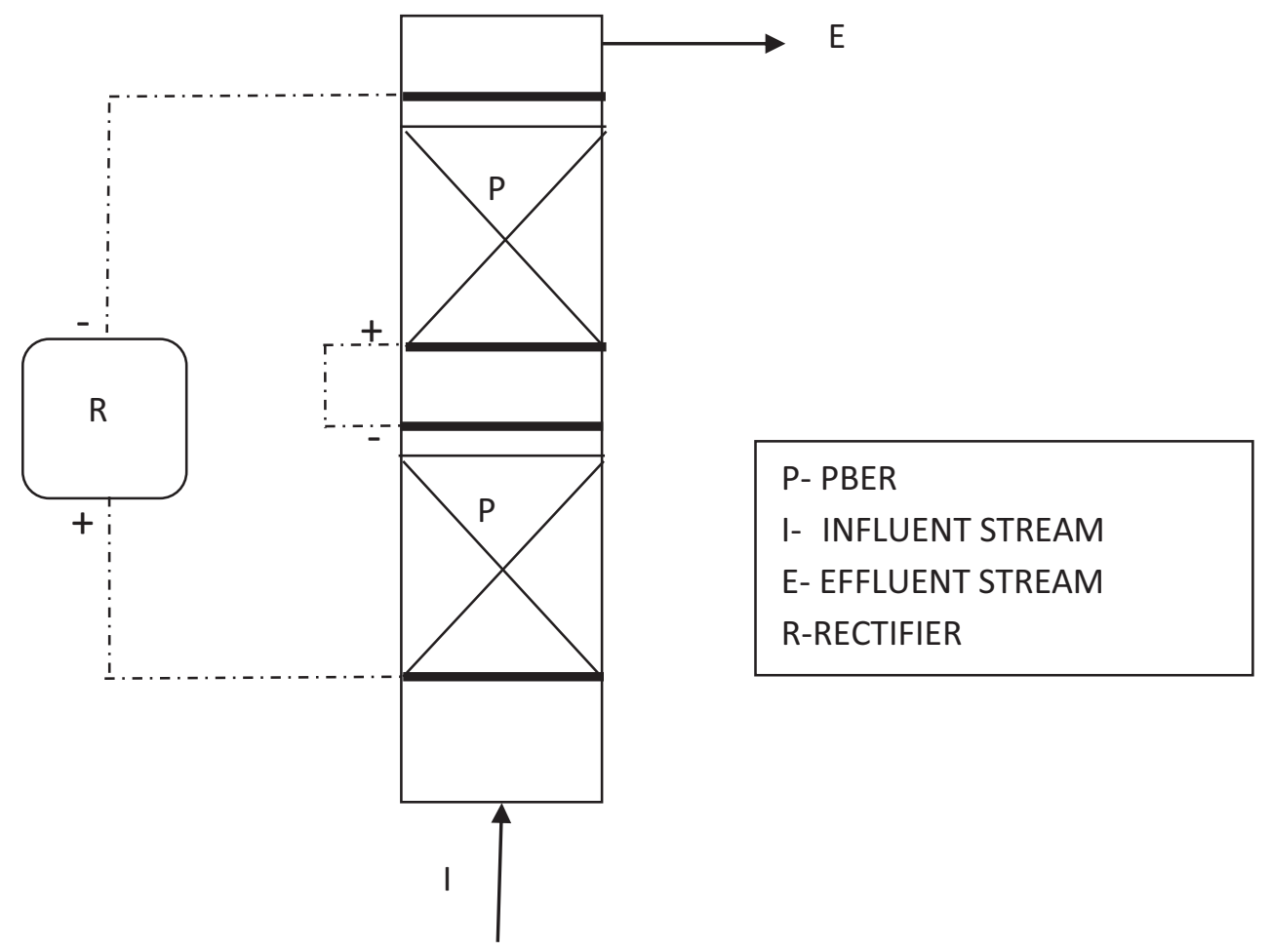

Fig. (3). Schematic sketch of Dual bed type cell. 


\section{RESULTS AND DISCUSSION}

\subsection{Effect of Current Density}

The effect of current density on the performance of single compact bed electrochemical cell was studied by maintaining temperature and electrolyte flow constant. Fig. (4), demonstrates the performance of a cell for each current load. The performance of the cell is assessed by calculating Perchlorate current efficiency. It is also found that the current efficiency during the beginning of electrolysis is varying with current density as depicted in Fig. (5). As expected, the performance of cell improves with the current density in the electron transfer control regime where higher over potential ensures better charge transfer reaction kinetics [8,9]. During this period, electron transfer rate predominates with current density resulting in improved reaction rate. As the current density is increased beyond $80 \mathrm{~A}$, graph follows through a maximum indicating that performance of the cell declined due to diminution of Chlorate radicals on the electrode surface. This observation is highly synonymous with the existence of mass transfer limit regime where the electrode surface is depleted with sufficient reactant radicals to undergo reaction [7]. During this period, the reaction rate proceeds faster as compared to diffusion of Chlorate radicals towards the electrode surface. Yet another observation is the methodical dropping of current efficiency with the weakening in the concentration of Sodium Chlorate, as shown in Fig. (6). This may most likely be due to the influence of limiting current density on the concentration of reactant species as per the equation given by Walker and Wagg in [10].

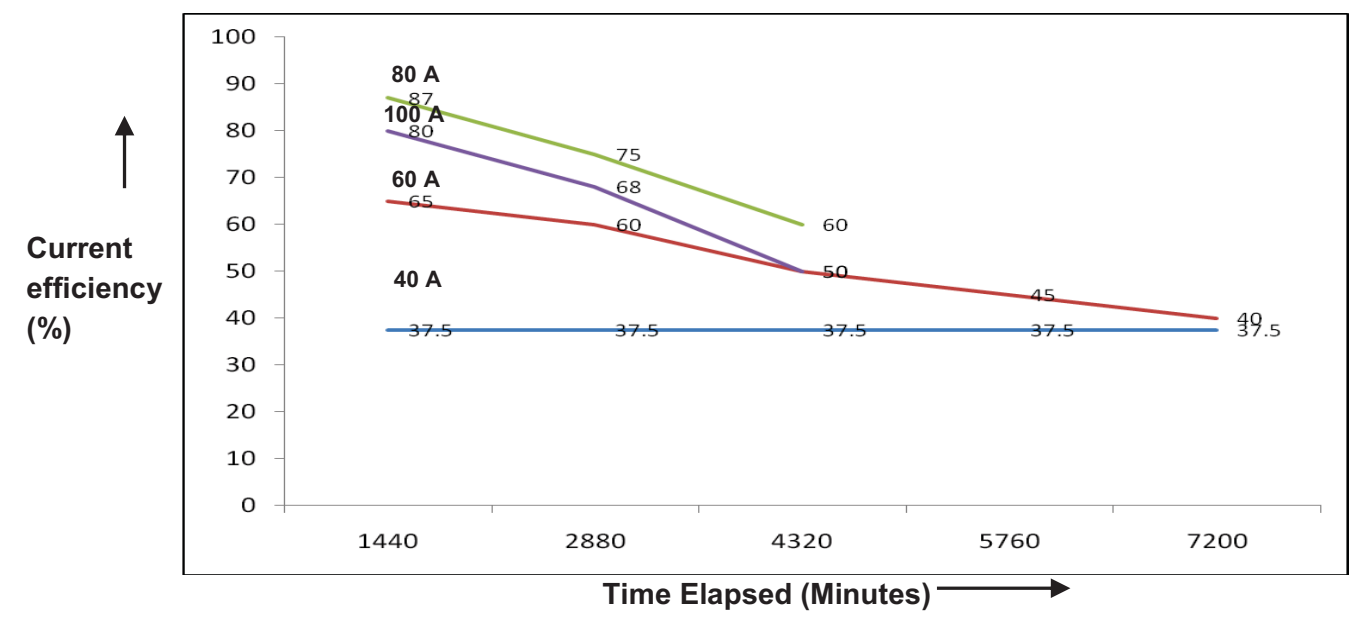

Fig. (4). Effect of current load (in amps) on performance of the electrolyzer

(Operating Conditions: Initial Conc. of $\mathrm{NaClO}_{3}=669 \mathrm{gpl}$, Flow Rate $=800 \mathrm{~mL} / \mathrm{min}$, Temperature $=60^{\circ} \mathrm{C}$, Bed $\mathrm{Height}=5 \mathrm{~cm}, \mathrm{Avg} \mathrm{Particle}$ $\mathrm{Dia}=700 \mu)$.

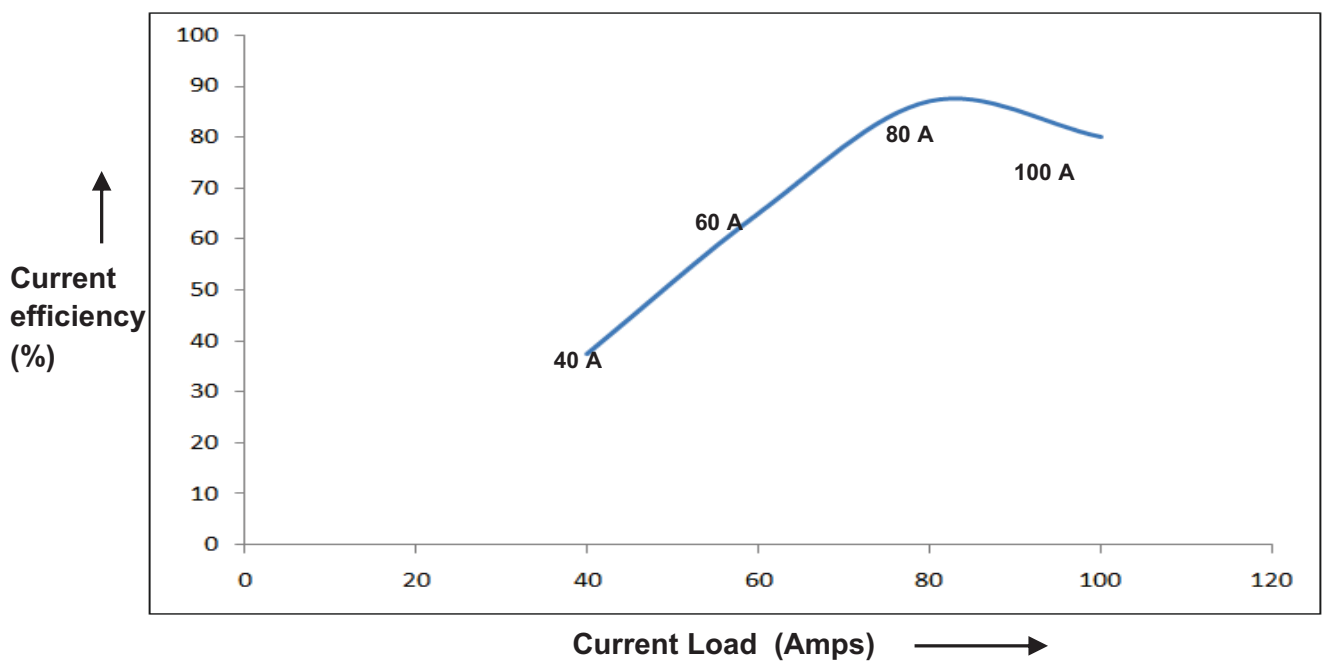

Fig. (5). Effect of initial current efficiency (CE) on current load. 


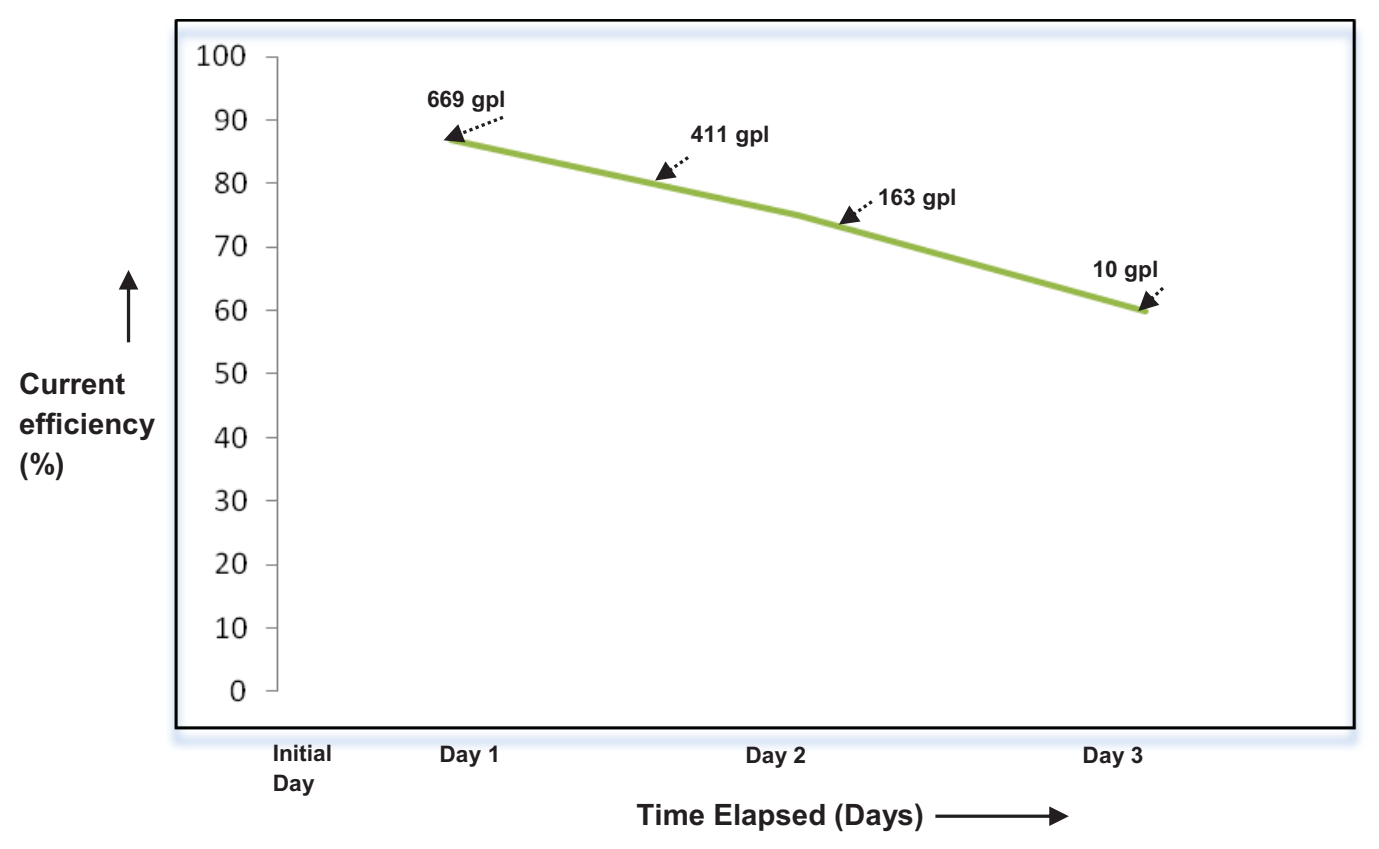

Fig. (6). Effect of concentration (in grams/lit (gpl)) of $\mathrm{NaClO}_{3}$ on $\mathrm{CE}$.

$\mathrm{I}_{\mathrm{L}}(\mathrm{t})=\mathrm{nFQC}_{\mathrm{i}}[1-\exp (-\mathrm{KAaL} / \mathrm{Q})]\{\exp (-\mathrm{t} / \tau)[1-\exp (-\mathrm{KAaL} / \mathrm{Q})]\}$

From the above equation, it is clear that limiting current density $\left(I_{L}(t)\right)$ is directly proportional to initial concentration $\left(C_{i}\right)$ of reactant species. Since the absolute value of limiting current density is an inherent indicative of the extent of reaction rate, observation concerning dropping of current efficiency with a decrease in initial concentration of Sodium Chlorate signifies eqn (1).

\subsection{Effect of Flow Rate}

Figs. ( $7 \& 8$ ), demonstrate the dependence of flow rate on the cell performance. Although, not as significant as current density, an optimal flow rate of $800 \mathrm{~mL} / \mathrm{min}$ was obtained. As the flow rate is increased ahead of this value, RTD (Residence Time Distribution) of the $\mathrm{ClO}_{3}$ species becomes inferior causing sizeable depletion in the current efficiency $[11,12]$. An additional observation is that the current efficiency gets faintly enhanced towards the end of reaction for higher flow rates $(>1000 \mathrm{~mL} / \mathrm{min})$. This may mostly be due to adequate accessibility of unconverted $\mathrm{ClO}_{3}$ species at the electrode surface at limiting current conditions, thereby somewhat triumphing over the resistance due to mass transfer.

\subsection{Effect of Temperature}

Temperatures ranging from $50^{\circ} \mathrm{C}$ to $70^{\circ} \mathrm{C}$ were chosen to study its dependence on the performance of the cell. The above temperature range was preferred considering the practically feasible range of study. Results are depicted in Figs. (9 \& 10). An optimum peak performance was observed at $60^{\circ} \mathrm{C}$, ahead of which the current efficiency drops down. This could be explained as follows. The basic mechanism for perchlorate formation is repeated from [13] as follows.

$$
\begin{gathered}
\mathrm{ClO}_{3}^{-} \rightleftarrows\left(\mathrm{ClO}_{3}\right)_{\mathrm{ads}}+\mathrm{e}^{-} \\
\mathrm{H}_{2} \mathrm{O} \longrightarrow(\mathrm{OH})_{\mathrm{ads}}+\mathrm{H}^{+}+\mathrm{e}^{-} \\
\left(\mathrm{ClO}_{3}\right)_{\mathrm{ads}}+(\mathrm{OH})_{\mathrm{ads}} \rightleftarrows \mathrm{ClO}_{4}^{-}+\mathrm{H}^{+}
\end{gathered}
$$

As shown above, the formation of perchlorate radical is a complicated heterogeneous electrochemical oxidation taking place through a sequence of steps. Generation of $\mathrm{OH}$ radicals by splitting of $\mathrm{H}_{2} \mathrm{O}$ molecule via one electron transfer step and its consequent adsorption on $\mathrm{PbO}_{2}$ surface will be the sluggish among all steps. Charge transfer rate along with the accessibility of $\mathrm{OH}$ radicals on the $\mathrm{PbO}_{2}$ surface are the two major prerequisites for the improvement in the rate of reaction and hence in current efficiency. Though electron transfer rate could be enhanced due to the higher solution conductivity with an increase in temperature, there could be a net reduction in the availability of $\mathrm{OH}$ radicals on the $\mathrm{PbO}_{2}$ electrode surface, due to the higher rate of desorption. This could be the most likely scenario for the above reduction in cell performance at higher temperatures.

In this way, for conducting a batch electrolysis using the above cells, the optimum values of important parameters like temperature, current density in each bed, and circulation flow rates, etc were determined. 


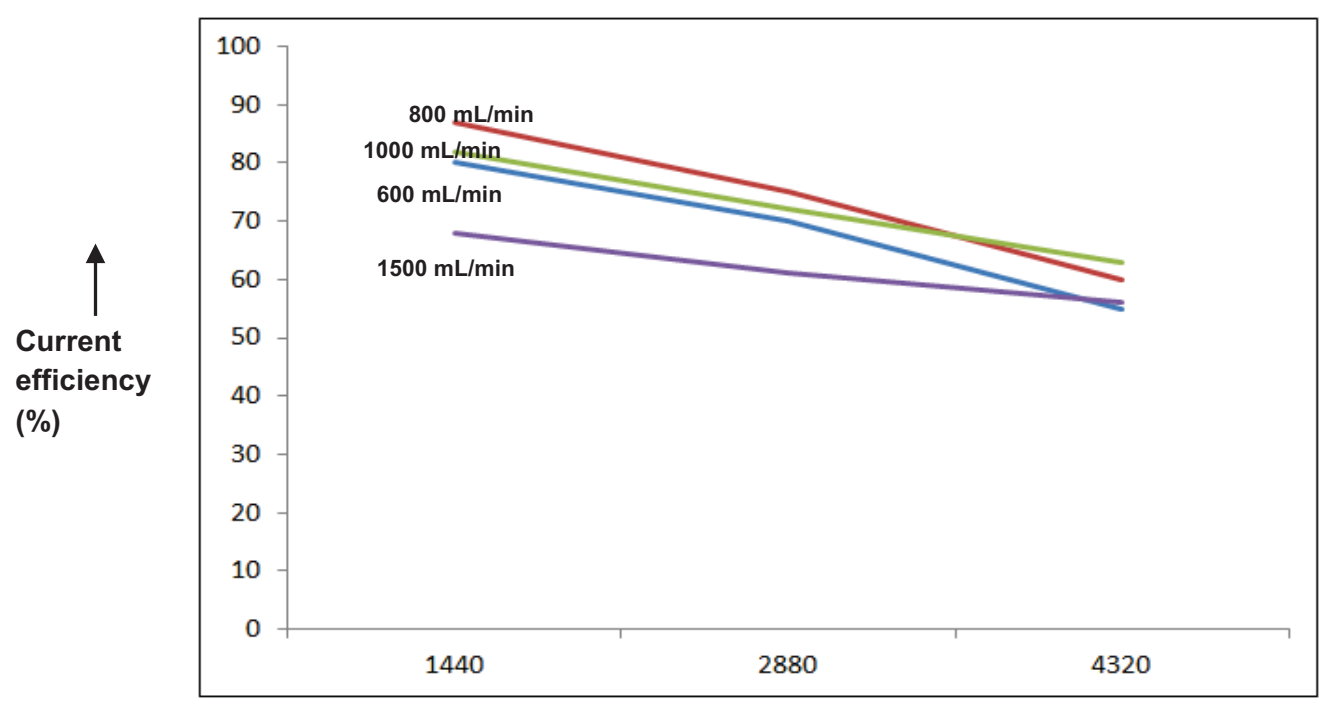

Time Elapsed (Minutes)

Fig. (7). Effect of flow rate (in $\mathrm{mL} / \mathrm{min}$ ) on performance of the electrolyzer

(Operating conditions: Initial Conc. of $\mathrm{NaClO}_{3}=669$ gpl, Current Load $=80 \mathrm{~A}$, Temperature $=60^{\circ} \mathrm{C}, \mathrm{Bed} \mathrm{Height}=5 \mathrm{~cm}, \mathrm{Avg}$ Particle Dia $=700 \mu$ ).

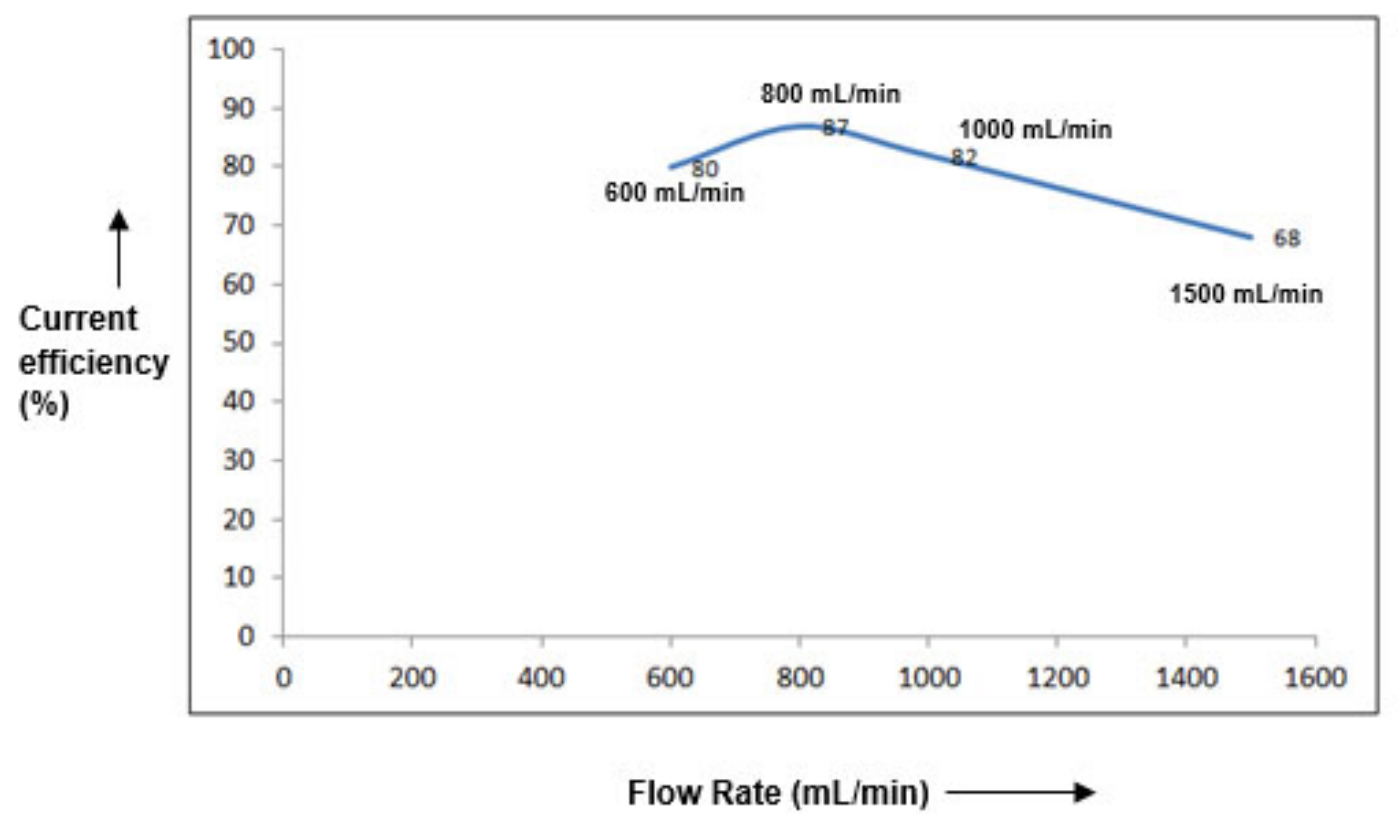

Fig. (8). Effect of initial Current Efficiency (CE) on electrolyte Flow Rate.

\subsection{Continuous Electro Synthesis of Sodium Perchlorate (SPC)}

Industrial manufacturing at higher scale of production always requires continuous mode of operation for keeping consistency in quality and to minimize space requirements. In order to resolve issues related to 'current penetration' at higher bed thickness, a dual bed type cell has been made in a single bed type by repeating one more bed of particles as mentioned in section 2.2. Four such dual bed compact electrochemical cells were arranged in a series by properly designing hydraulic circuits so as to transfer adequate flow of electrolyte to the subsequent cells as well as for providing sufficient recirculation. Cooling of electrolytes was ensured by providing a jacketed product cooler capable of removing heat from the system by circulation water through its jacket. A definite proportion of electrolyte from the cooler was taken as the final product and the remaining portion was recycled back to the system. A schematic sketch of the system is shown in Fig. (11).

As the feed electrolyte enters and flows upwards through the electrically charged bed, incremental conversion to Sodium 
perchlorate occurs at each stage and would overflow to the adjacent cell. In this way, the output from the product cooler was analysed transiently for getting the concentration of $\mathrm{NaClO}_{3}$ in product SPC. This procedure signifies the extent of conversion of Sodium Chlorate to Sodium Perchlorate inside these cells. Initially, cells were charged in recirculation mode without feeding the fresh $\mathrm{NaClO}_{3}$ solution. This period is termed as "stabilization period" where the initially filled Sodium Chlorate solution is converted completely to SPC solution having desired concentration. Beyond this, "conti-nuous flow period" starts where the fresh feed is fed in at a defined flow rate and the product is withdrawn at the same rate. As mentioned earlier, a definite proportion of output electrolyte is fed back to the system for maintaining adequate recirculation for cooling purpose. Fig. (12), depicts the transient behavior in the concentration of $\mathrm{NaClO}_{3}$ in the collected product.

From the above graph, it is clear that there is a significant rise in the concentration of $\mathrm{NaClO}_{3}$ in the product solution after elapsing a definite time period, in comparison with the predicted one. This emphasizes the incompletion of reaction even after traversing through all the cells arranged in series. Recirculation of cooled electrolytes to individual cells causes the flow disturbances, which increases the problems.

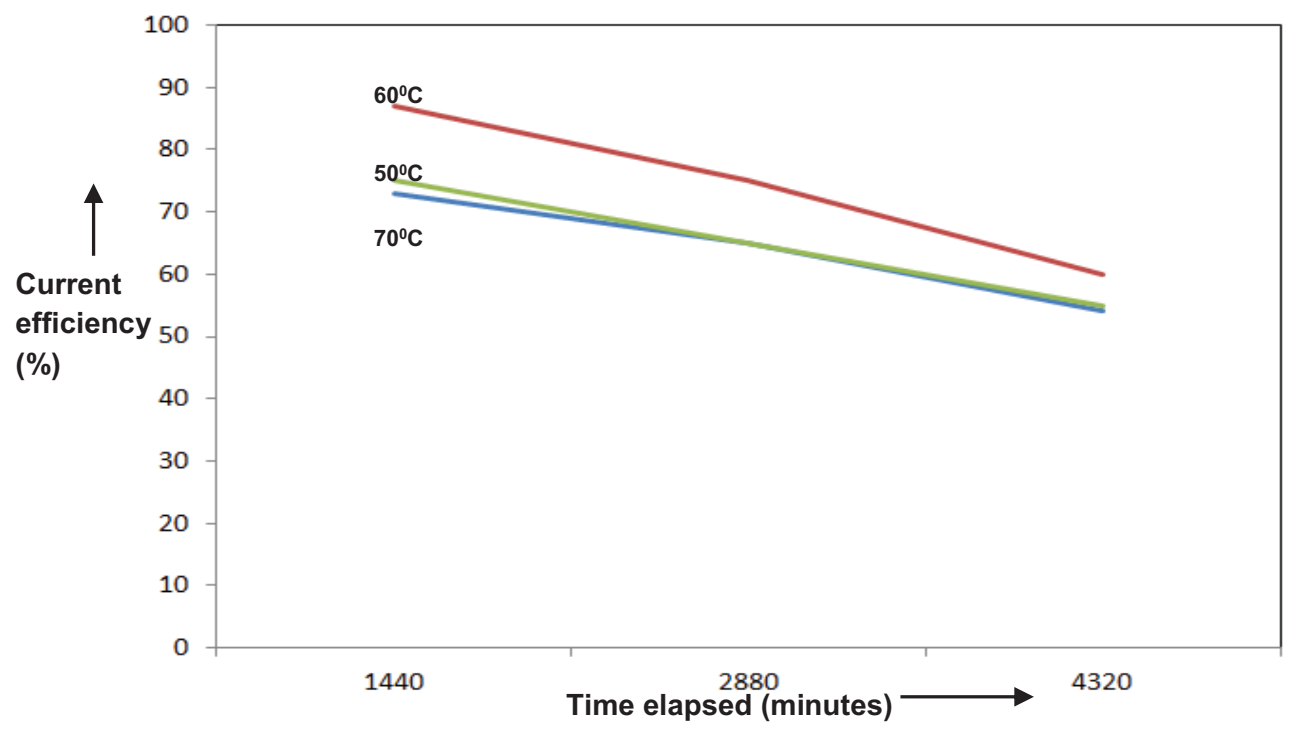

Fig. (9). Effect of temperature (in deg. Celsius) on performance of the electrolyzer

(Operating Conditions: Initial Conc. of $\mathrm{NaClO}_{3}=669$ gpl, Current Load $=80 \mathrm{~A}$, Temperature $=60^{\circ} \mathrm{C}$, Bed Height $=5 \mathrm{~cm}$, Avg Particle Dia $=700 \mu$ ).

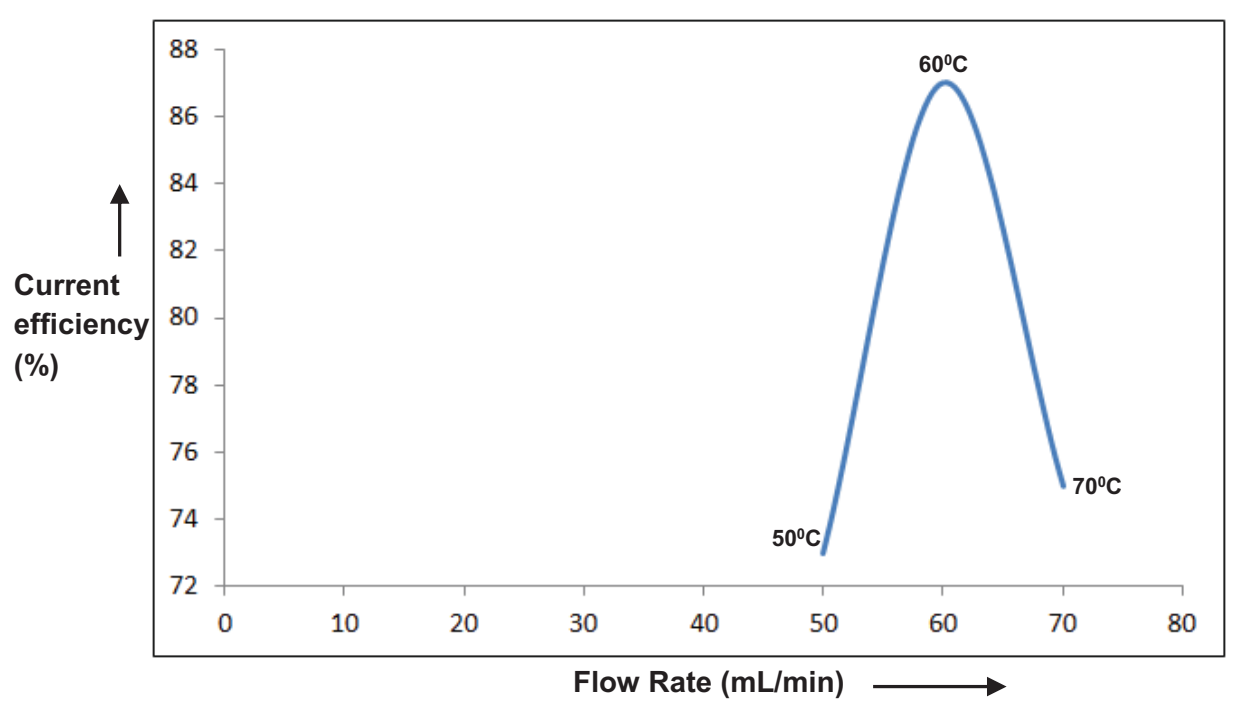

Fig. (10). Effect of initial Current Efficiency (CE) on electrolyte temperature. 


\subsubsection{Modifications/Improvements Carried Out}

The above issues were resolved by introducing line condensers between each cell and modifying orientation of cells as depicted in Figs. (13 and 14). The introduction of line condensers for electrolyte cooling avoids the necessity of having independent electrolyte circulation streams to each cell. Rigorous back mixing inside cells, offered by recirculation loop, primarily disturbs the flow dynamics resulting in poor conversion. Line condensers between cells remove the ohmic heat of electrolyte as well as smoothens the electrolyte flow through bed, thereby tantamounting to plug flow mode. From Fig. (14), it is clear that the $4^{\text {th }}$ cell was disconnected from the cascade and introduced as a 'polishing cell'. This cell needs to deal only with the end stage electrolyte (preferably $<100$ gpl
Sodium Chlorate in electrolyte) having only a lean concentration of Sodium Chlorate overflowing from the product cooler. It is known from experience that a significant drop in current efficiency is noticed when the concentration of reactant radicals (here Sodium Chlorate) drops below 100 gpl. This could be the potential reason behind the mal-performance of the previous configuration as depicted in Fig. (12). To a greater extent, this sluggishness in performance can be triumphed by advocating enough residence time for the electrolyte specifically in its end stages. The introduction of polishing cell thus provides ample residence time for electrolyte overflown from the intermediate cooler which is approaching its final stage conversion. The improvement in performance of the system is is shown in Fig. (15).

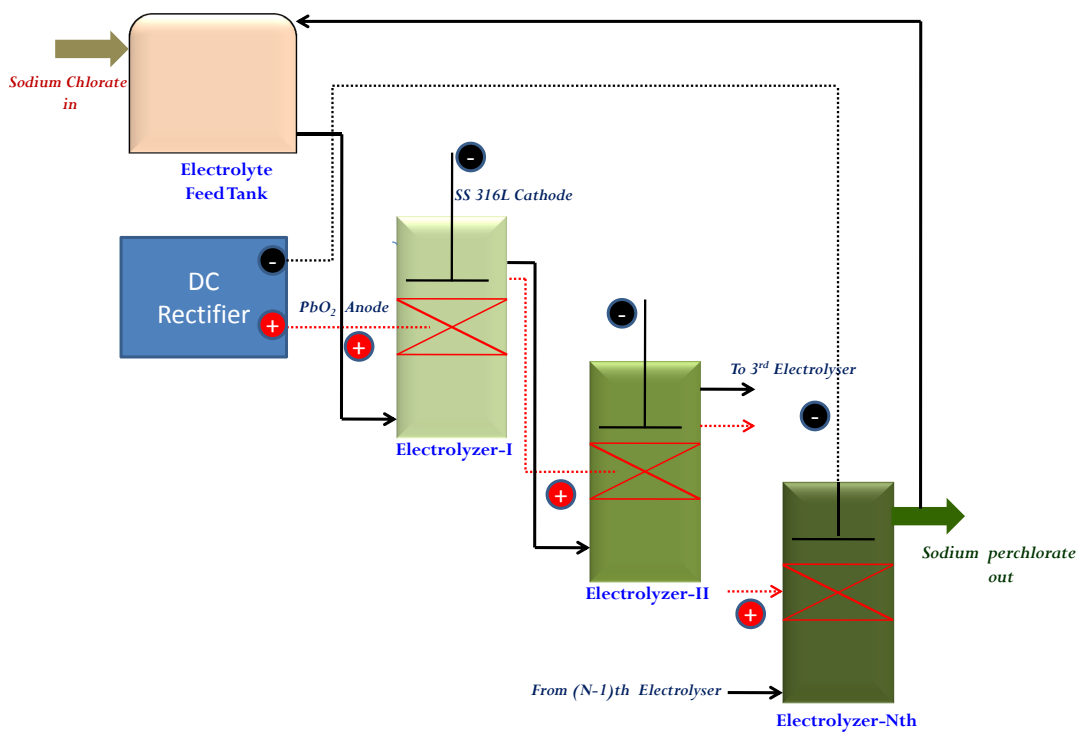

Fig. (11). Schematic sketch for continuous electrosynthesis of Sodium perchlorate (SPC).

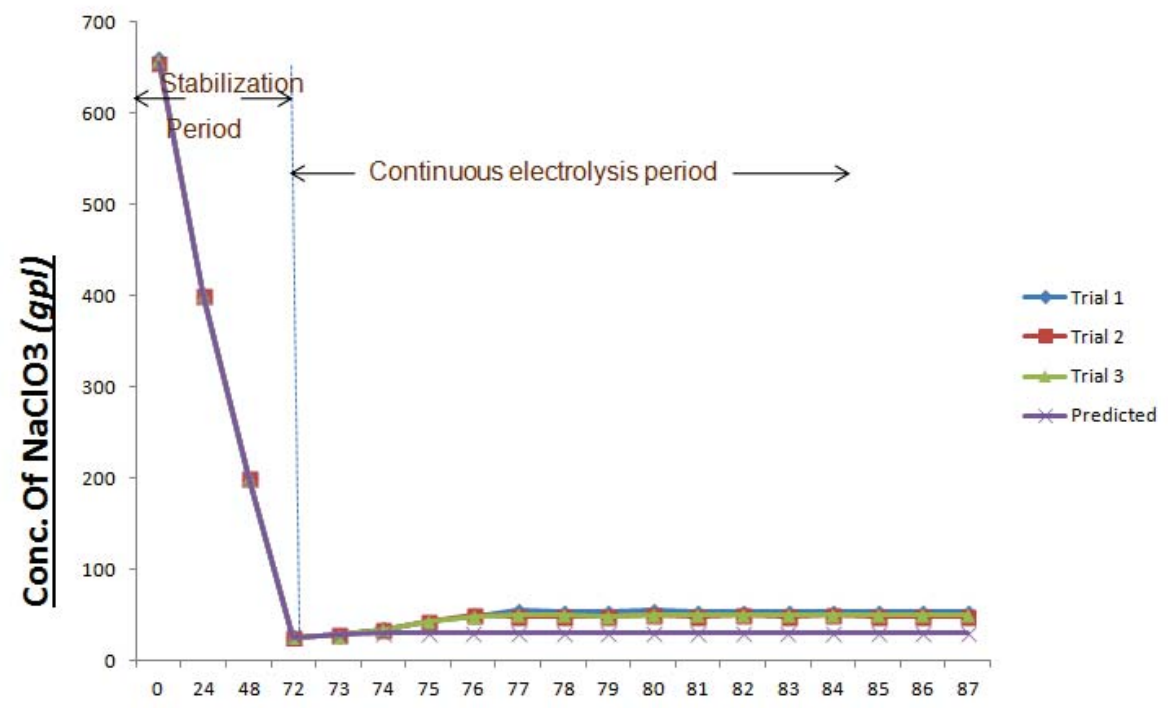

Time elapsed (hrs)

Fig. (12). Transient behavior in $\mathrm{NaClO}_{3}$ conc. in product. 


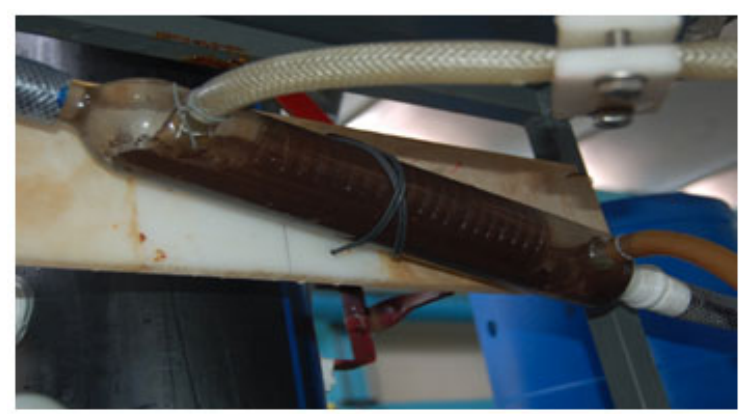

Fig. (13). Inline condensers.

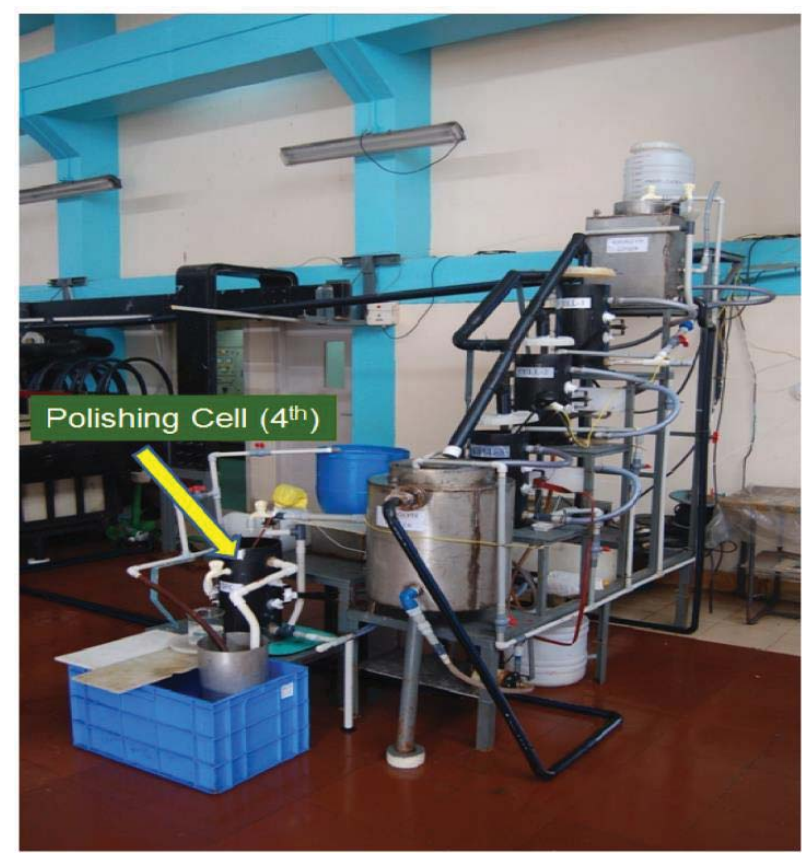

Fig. (14). Modified orientation of $4^{\text {th }}$ cell.

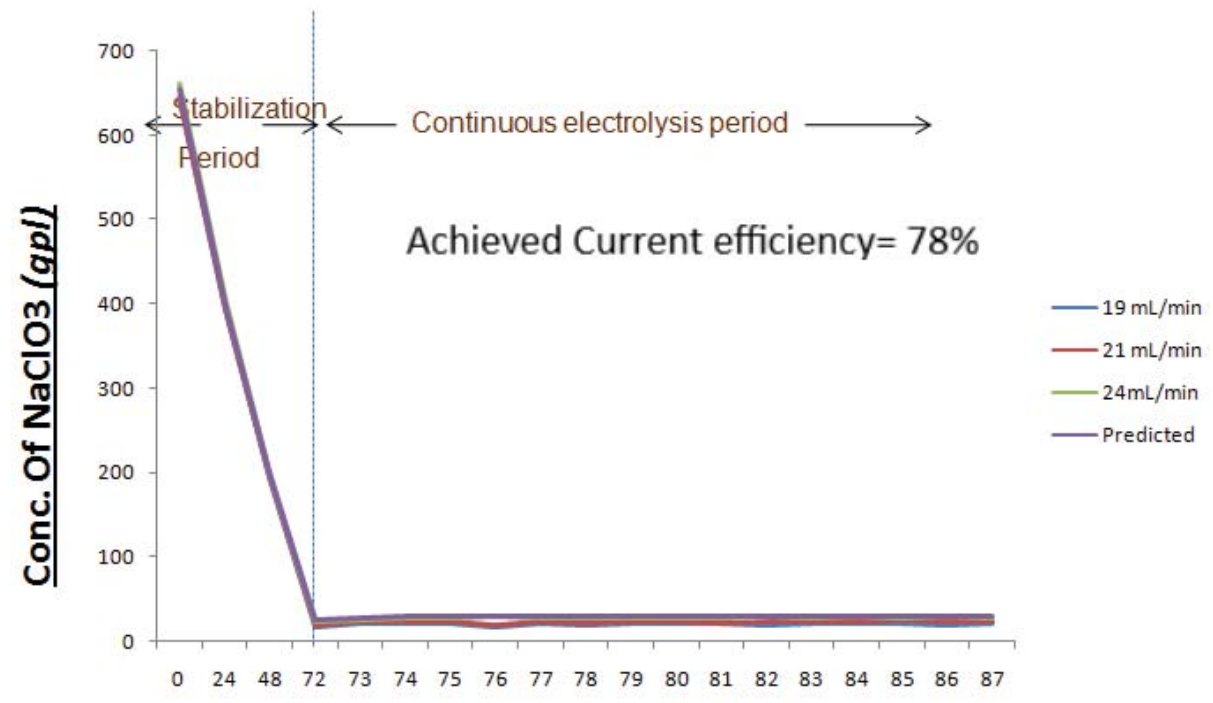

\section{Time elapsed (hrs)}

Fig. (15). Transient behavior in $\mathrm{NaClO}_{3}$ conc. in product. 


\section{CONCLUSION}

A compact flow-through electrochemical cell using discarded lead dioxide particles in single and dual bed configuration was developed for effective and energy efficient production of Sodium perchlorate. Being the most cost effective and energy efficient, this electrolyser outperforms the conventional parallel plate design. Yet more attractive takeaway of this module is the total exclusion of costly inert conductive support and mixed metal oxide $(\mathrm{Ru}, \mathrm{Pd}, \mathrm{Ti})$ conductive coating essential for conventional flat plate configuration. A demonstration of continuous electrosynthesis of Sodium perchlorate by arranging similar dual bed compact electrochemical cells was made and an average current efficiency of about $78.5 \%$ could be achieved which is $20-25 \%$ higher than conventional parallel plate electrode system. Additionally, the service life of these 'particle' electrodes will be highly promising for industrial scale level, since the life of conventional lead dioxide coated anode is defined till $\mathrm{PbO}_{2}$ gets attached to the conductive substrate like Titanium.

\section{ETHICS APPROVAL AND CONSENT TO PARTI- CIPATE}

Not applicable.

\section{HUMAN AND ANIMAL RIGHTS}

No animals/humans were used for studies that are basis of this research.

\section{CONSENT FOR PUBLICATION}

Not applicable.

\section{CONFLICT OF INTEREST}

The author declares no conflict of interest, financial or otherwise.

\section{ACKNOWLEDGEMENTS}

I hereby acknowledge the Ammonium perchlorate Experimental Plant, a unit of Vikram Sarabhai Space Centre \& Cochin University of Science \& Technology, for supporting me in this work.

\section{REFERENCES}

[1] X. Li, D. Pletcher, and F.C. Walsh, "Electrodeposited lead dioxide coatings", Chem. Soc. Rev., vol. 40, no. 7, pp. 3879-3894, 2011. [http://dx.doi.org/10.1039/c0cs00213e] [PMID: 21431116]

[2] J.P. Carr, and N.A. Hampson, "Lead dioxide electrode", Chem. Rev., vol. 72, pp. 679-703, 1972

[http://dx.doi.org/10.1021/cr60280a003]

[3] Onwughara, "Focus on potential environmental issues on plastic world towards a sustainable plastic recycling in developing countries", Int. J. of Ind. Chemistry., vol. 4, p. 34, 2013. [http://dx.doi.org/10.1186/2228-5547-4-34]

[4] J.S. Newman, and C.W. Tobias, "Theoretical analysis of current distribution in porous electrodes", J. Electrochem. Soc., vol. 109, pp. 1183-1191, 1962.

[http://dx.doi.org/10.1149/1.2425269]

[5] L. Wang, "Optimal wastewater treatment using a Packed-Bed Electrode Reactor (PBER): From laboratory experiments to industrialscale approaches", Chem. Eng. J., vol. 334, pp. 707-713, 2018. [http://dx.doi.org/10.1016/j.cej.2017.10.124]

[6] P. Ning, "Accelerated desulphurization of waste lead battery paste in a high-gravity rotating packed bed", Chemical Engineering and Processing: Process Intensification., vol. 104, pp. 148-153, 2016. [http://dx.doi.org/10.1016/j.cep.2016.03.007]

[7] L. Wang, "Kinetics for electro-oxidation of organic pollutants by using a packed-bed electrode reactor (PBER)", Chem. Eng. J., vol. 284, pp. 240-246, 2016.

[http://dx.doi.org/10.1016/j.cej.2015.08.132]

[8] T. Doherty, "An improved model of potential and current distribution within a flow-through porous electrode", Electrochim. Acta, vol. 41, pp. 519-526, 1996.

[http://dx.doi.org/10.1016/0013-4686(96)81774-9]

[9] N.M.S. Kaminari, "Study of the Operational Parameters Involved in Designing a Particle Bed Reactor for the Removal of Lead From Industrial Wastewater Central Composite Design Methodology", Chem. Eng. J., vol. 105, pp. 111-115, 2005. [http://dx.doi.org/10.1016/j.cej.2004.07.011]

[10] A.T.S. Walker, and A.A. Wuagg, "The modelling of concentrationtime relationships in recirculating electrochemical reactor systems", Electrochim. Acta, vol. 22, pp. 1129-1134, 1977. [http://dx.doi.org/10.1016/0013-4686(77)80051-0]

[11] Y. Volkman, "Analysis of the performance of packed-bed electrochemical reactors", J. Appl. Electrochem., vol. 8, pp. 347-352, 1978 .

[http://dx.doi.org/10.1007/BF00612688]

[12] J.A. Trainham, and J. Newman, "A Flow-Through Porous Electrode Model: Application to Metal-Ion Removal from Dilute Streams", J. Electrochem. Soc., vol. 124, pp. 1528-1540, 1977. [http://dx.doi.org/10.1149/1.2133106]

[13] N. Munichandraiah, and S. Sathyanarayana, "Kinetics and mechanism of anodic oxidation of chlorate ion to perchlorate ion on lead dioxide electrodes", J. Appl. Electrochem., vol. 17, pp. 33-48, 1987. [http://dx.doi.org/10.1007/BF01009129] 